\title{
How Restorative Justice Practices Create Safer, More Caring School Communities
}

\author{
Sage Streight
}

\section{Introduction}

$\mathrm{T}$ RADITIONALLY, the Western model of justice has been one that reflects a retributive paradigm. The structure of this model has been hierarchical and offender-focused, with the primary goal of punishing offenders for their actions and getting "an eye for an eye" (Drewery, 2004, p. 334). Offenses are deemed to be offenses against the state, and so it is the state that is responsible for sentencing and punishment, according to the law (Drewery, 2004). This retributive paradigm is most prudently observed within Western criminal justice systems, but is also reflected within Western educational systems. Within schools, the main feature of student-to-teacher relationships is based on control (Varnham, 2005). School principals, teachers, and administrators are to enforce and protect the rules in schools and wherever students engage in disruptive, anti-social behaviour by which relationships and school community are threatened. Schools react to deviant behaviour by imposing exclusionary sanctions such as detentions, suspensions, or expulsions that aim to control (Varnham, 2005). When I use "traditional school behaviour mechanisms", I am referring to these. In fact, suspensions are widely used in schools with little evidence that they make schools safer and prevent misbehaviour (Gregory, Clawson, Davis, \& Gerewitz, 2015). The American Academy of Pediatrics issued a statement describing the effectiveness of exclusionary sanctions as "increasingly questionable" (Gregory et al., 2015, p. 1). A further study discovered that with each additional suspension of a student, his or her odds of graduating high school decreased by $20 \%$ (Gregory et al., 2015, p. 2). Additionally, pre-emptive measures are introduced into schools to prevent such behavior, which creates a feeling of distrust within school communities and has proven to be ineffective at fostering long-term school safety (Varnham, 2005).

Clearly, the current retributive model used in schools is widely becoming recognized as harmful and ineffective in its goals to deter misbehaviour, make schools safer, and create communities of care within schools. The concern of safety in schools is one of physical safety as schools have high incidents of bullying and physical violence (Morrison, 2003). Due to this, many efforts have been put towards dealing with issues in schools through a restorative justice paradigm. Restorative justice $(\mathrm{RJ})$ is rooted in indigenous traditions based on practices that value living in harmony and restoring that harmony when it is disrupted (Ortega, Lyubansky, Nettles, \& Espelage, 2016). In contemporary Western society, RJ focuses on repairing the harm caused by wrongdoing and bringing together victims, offenders, and the wider community to do that (Ortega et al., 2016). This physical act of bringing people together to resolve conflict creates understanding and connection that strengthen communities and develop "communities of care," which means community that recognizes how harm can result and values restoring the harm done together.

There are varying forms that RJ practices can take, and many schools in North America have been implementing RJ practices in various ways to address prominent issues of bullying, disciplinary issues, and interpersonal conflicts (Karp \& Breslin, 2001; Stinchcomb, Bazenmore, \& Riestenberg, 2006). One type of RJ practice is the peacemaking circle. Circles are processes that encourage participants to resolve conflicts and matters of injustice together through facil- 
itated communication and collective decision-making (Coates, Umbreit, \& Vos, 2003). This paper will seek to prove the effectiveness of circles by first presenting the role of schools in the broader social community and then go into more details about what RJ is, why it fits within the school context, how RJ works in schools, and the use and results of RJ peacemaking circles in schools. The remainder of this paper will show that, due to the current ineffectiveness of traditional school behaviour mechanisms in schools and the growing use of RJ practices, the use of circles in schools is proven more effective at creating communities of care, ultimately making schools safer.

\section{The Function of Schools}

It has been stated that RJ practices are helping schools move away from a retributive paradigm to one that is more therapeutic and holistic (Gunn, 2018). This is important in schools because these institutions are tasked with a very important role in Western society: the socialization of children. Social institutions facilitate socialization, moral integration, and social control (Karp \& Breslin, 2001). In fact, the United Nations Convention on the Rights of the Child state that education should be directed to "the preparation of the child for responsible life in a free society, in the spirit of understanding, peace, tolerance, equality of sexes, and friendship among peoples, ethnic, national, and religious groups, and persons of indigenous origin" (Varnham, 2005, p. 100). Therefore, it is easy to see how the structure of school, treatment in schools, and things learned in school have a huge influence on the norms and patterns of behaviour that people develop. Because of this there is strong support for the idea that a school culture needs to cultivate values of worth in young persons, and encourage participation in all matters within a school community in order to not only benefit the school, but instill positive social behaviour that will benefit the future direction of society (Varnham, 2005).

In addition to the task of socialization that our schools undertake is the obvious task of behaviour management. Many children, especially in younger years, misbehave in schools not because they are "bad", but because they are not able to deal with their needs in a productive, positive way (Pakan, 2007). Through various responses to and punishments of misbehaviour, kids are taught how to behave; however, traditional school behaviour mecha- nisms fail in that they focus on individual penalties when rules are broken and do not constructively respond to incidents of misbehaviour that teach children how to deal with their needs more constructively or to understand the repercussions of their negative actions on others (Cameron \& Thorsborne, 1999). Research has found that this lack of positive behaviour management in schools causes students who misbehave to not truly experience accountability for their actions and thus become a high risk for repeating such behaviour outside of the school environment (Varnham, 2005, p. 88). Schools clearly need to move to more constructive ways to deal with misbehaviour, methods that teach students positive ways to meet their needs and facilitate more meaningful involvement in building community.

The final reason RJ is needed within schools is that schools have high levels of violence (Morrison, 2003). Insidious violence such as bullying, aggression, intimidation, and exclusion are not only harmful in themselves but feed into a wider cycle of violence and alienation within social communities (Morrison, 2003). Additionally, these forms of violence usually have long-term negative effects on both offenders and victims (Morrison, 2005). Current punitive reactive measures to violence are not effective at ensuring safety in schools; it is clear that there is a need for RJ values and practices to restore relationships and bring accountability, helping make schools safer (Varnham, 2005).

Socialization, behaviour management, and violence in schools are three things that are contributing to how schools operate and, therefore, how safe they are. These three factors teach staff and students within schools what is appropriate and what kind of environment the school will be. Therefore, it is imperative that these three things be managed and addressed in the most positive and constructive way, which is not being done with the current retributive approach. The rest of this paper will seek to show how RJ practices are necessary in schools as they help to reduce delinquent behaviour and foster positive socialization that is beneficial to the whole of society.

\section{RJ and Its role in Schools}

RJ is defined as "a non-adversarial, non-retributive approach to justice that emphasizes healing in victims, meaningful accountability of those responsible 
for harm and the involvement of citizens in creating healthier, safer communities. Restorative justice works to repair the damage and promote healing and growth" (Pakan, 2007, p. 2). RJ emphasizes respect and relationships while upholding dignity, addressing human needs, and empowering participants to discuss their experiences openly and honestly (Morrison, 2003; Pakan, 2007). RJ brings parties together to talk through what happened, who was affected and how, and what needs to be done to repair the harm (Morrison, 2003). The objective of RJ is to build a peaceful community, one where it is possible for various people to get along and understand each other (Drewery, 2004). RJ does this as it empowers individuals to be responsive to their own needs and to the needs of the community through participation, being accountable, and showing support (Morrison, 2003). RJ provides an opportunity for all involved to learn and grow together as it values "healing over hurting, inclusion over exclusion" (Morrison, 2003; Morrison, 2005). In this way, RJ at a community level is about reducing crime and harmful behavior, and at a personal level, is about enabling individual change through discharge of negative feelings and building of positive feelings (Morrison, 2003). RJ practices turn conflict into cooperation and facilitate behavioral changes (Morrison, 2003).

RJ practices have been criticized for being inapplicable to broader "crimes" in schools, such as cheating on tests, that do not directly seem like interpersonal issues. But, in the school environment, RJ is used in reactive and preventative ways to create an "ethos of care and social and emotional learning," showing that RJ is more than a set of procedures that occur after a rule infraction, but is used to change how a school operates on a day-to-day basis (Gregory et al., 2015, p. 4). RJ changes school communities in the same way, by facilitating cooperation and behavioral changes among staff and students and between them. This results in understanding, community, and an atmosphere of safety that comes to view harm done in schools not in terms of its technical violation but by its effect on others within the school community (Cameron \& Thorsborne, 1999; Karp \& Breslin, 2001). This paradigm shift in the notion of harm, facilitated by RJ, means that in a response to acts of misbehaviour and violence, schools will look at the web of relationships, the needs unmet, and deeper issues present that have manifested in harmful be- haviour (Morrison, 2003). This means that RJ practices in schools seek to address all matters within incidents of harm and provide understanding and lessons learned that can be used for personal growth and positive community relations (Cameron \& Thorsborne, 1999; Pakan, 2007). To use the example given above, instead of just being given a fail or detention, cheating on a test could be dealt with by discovering why the cheating occurred, understanding that the cheating is harmful to the integrity of the school, and also harmful to the personal integrity of the individual, and disrupts their educational development. If a student is given the chance to see the depth of impact that this cheating has on the school and themselves, it creates a sustainable change in behaviour. This is how this shift in understanding of harm is extremely powerful as it is one of the main reasons $\mathrm{RJ}$ in schools has proven to be effective, making schools safer by fostering understanding in communities of care rather than excluding and punishing individual students.

Additionally, an RJ approach to problem-solving in schools makes individuals accountable for the aspects of structure, policy, organization, curriculum, and pedagogy that have contributed to harm and injury within school communities (Cameron \& Thorsborne, 1999). RJ empowers students, teachers, administrators, victims, offenders, and the whole community to take a step back and look at who is responsible for the harm done, and what is the best way to deal with that harm in order to ensure growth, deterrence, safety, and rehabilitation for those directly involved and for the wider school community (Morrison, 2005). RJ encourages everyone to play a part in keeping their school safe and building a school community that cares (Varnham, 2005). Clearly, the themes of RJ align with a school's goals of reducing harm and making schools safer through distinct techniques that effectively instill these messages in students.

\section{Tools of RJ: The Circle}

Usually, when students are in trouble at school they sit across from an adult and are confronted with their behavior. This is a situation where great authority and power are given to the adult while the child is put on the defensive (Gunn, 2018). As explained in the introduction, this dynamic does not allow misbehaviour to be constructively resolved. Circles remove this concept of authority and punishment, physically 
opening all participants to face one another (Gunn, 2018). The goal of circles is to hold a space that promotes understanding, self-responsibility, and action (Ortega et al., 2016). The circle is a facilitated dialogue in which all individuals are supported by the facilitator in understanding each other and taking responsibility for their choices. Facing one another, participants have frank and open discussions about academic and classroom-specific topics that allow students and teachers to learn about one another, respond to breaches of trust, and potentially develop a sense of shared authority and ownership over the classroom climate, resulting in increased accountability and community (Gregory et al., 2015).

These goals are all proven successful in a study done by Ortega et al. (2016) where they implemented circles in many schools in the US. In the study, it was found that over $40 \%$ of the circle participants indicated that having offenders take responsibility and being held accountable for their actions was one of the most important results of the circle process (p. 464). This fosters respect and connection with others, empowering individuals to act in the interest of the group, which increases pro-social behaviour and decreases anti-social behaviour in the school context (Morrison, 2005). This outcome is hard to achieve in more isolating, punitive practices such as those currently used in a traditional paradigm (Gregory et al., 2015). In fact, Ortega et al.'s study (2016) conclusively found that adult participants acknowledged the ineffective nature of current punitive ways of handling misbehaviour and conflicts (p. 466). Furthermore, circles have been proven to lower suspensions in favor of social-emotional strategies that foster relationships (Gunn, 2018). Circles have also been found to improve emotional intelligence, encourage productive conflict resolution, and create an environment where concern for well-being is fostered between students and teachers (Morrison, 2003, p. 700). Braithwaite (2001) states that circles invoke a hidden curriculum that teaches students to "listen, to accommodate others' perspectives, and to live in a civil society where democracy can flourish because individuals have been educated how to properly govern their own behaviors and lives" (p. 46). Circles are clearly in line with the ultimate goal of schools to prepare young citizens for success in broader social communities, and are more effective at achieving this than traditional mechanisms.
These results of RJ circles in schools are not hard to believe when we understand that circles create positive dialogue and promote communities of care that ultimately make social spaces safer. This positive dialogue and understanding go hand in hand with creating a community of care in schools. "By recognizing the potential for healing, empowerment of individuals, bringing relationships back into balance and strengthening communities, schools have begun to adapt and to adopt restorative justice practices" (Pakan, 2007, p. 12). A shift to RJ practices and use of circles can change the social culture of school communities, reduce violent behavior, and make schools safer (Morrison, 2005). These changes are not to be taken lightly when schools are tasked with such important functions like socialization and behaviour management.

\section{Implementation of RJ Circles}

At this point, it is necessary to talk about how circles can be implemented in schools as a restorative justice practice. The discussion is based on the suggestions and vision of Braithwaite (2001). As mentioned, existing programs have failed to effectively deal with youth problems because the current traditional paradigm approaches young people as isolated individuals. Since offences are community-driven, the resolution must be too. Therefore, circles would not aspire to treat students as isolated individuals, targeted because of their problems. This treatment stigmatizes them as individuals, which, as presented, is an unsuccessful mechanism for conflict resolution. To avoid targeting in an unproductive way, circles would be provided universally to young people in a school, not just to the problem students (Braithwaite, 2001). Circles would allow for choices to opt for rehabilitative services in networks of support that build commitment to make them work (Braithwaite, 2001). Braithwaite (2001) envisions circles implemented at every grade level within classrooms as a consistent practice in grade schools. Braithwaite (2001) wants to create an institutional infrastructure to foster the emergence of this informal support in schools. This "institutionalization would build a citizenship obligation to participate in circles and that the circles would lend ritual power to informal support" so that circles will become an everyday practice that people use to resolve conflicts (Braithwaite, 2001, p. 245).

It is important to note that RJ circles can be 
criticized for focusing so much on practice and interpersonal behaviour that it forgets institutional procedures that sustain school communities, such as a board of directors making decisions on health and safety regulations. Building a safe and healthy school community does need to go hand and hand with how schools are regulated (Morrison, 2005). What RJ practices, and specifically RJ circles, seek to expose is that policy development and practices need to be embedded into the school community, rather than "handed down" by higher authority in order to be responsive to the school community needs (Morrison, 2005). This relationship between policy and individual is widely recognized as the effectiveness of a policy is only as great as the policy's ability to fulfill individual needs. This is where the use of RJ circles in schools is powerful: they effectively allow necessary "top-down" procedures to be implemented and processed at an interpersonal level through open conversation, understanding, responsibility-taking, and the natural creation of a community that cares when people take the time to develop trusting relationships. As such, they are easy to implement, require little resources, and are a healthy and productive use of school time.

\section{Conclusion}

An education system that embraces greater participation in school decision making and restorative justice practices offers a perfect opportunity to work towards addressing the concerns that schools face with the current traditional school behaviour mechanisms. Schools need communities of care, proper socialization, and proper behaviour management in a cohesive and holistic manner (Varnham, 2005). RJ practices, specifically circles, enable school communities to be more responsive, restorative, and responsible in addressing harmful social behavior. More specifically, RJ practices increase a school's capacity to build human and social capital, and to ensure the social and emotional well-being of the school community, which is imperative to effective learning and safety to all (Varnham, 2005). RJ and circles in schools satisfy the social and emotional needs of the school community, reduce the risk of violence in schools, and harness the capacity for the building of civil society (Morrison, 2001). Overall, circles as an RJ practice increase a school community's capacity to learn and grow together through fostering responsible citizenship where individuals are aware of the consequences of their actions, given tools to constructively deal with their needs, and are instilled with a vested interest in the well-being of those within the school and wider community. A powerful statement by Kiare, a grade-nine student attending an Oakland, California school, sums up the effects of circles in schools at creating communities of care that ultimately make schools safer. She says that "circles have made me treat people better because I see how people are" (Friedman, 2012, 6:03). This statement shows that when we see who people are through conversation and connection, then we come to recognize how our actions influence those around us. More so than traditional mechanisms, circles as an RJ practice facilitate this awareness in schools which creates communities of care where people think empathetically rather than selfishly, ultimately filling schools, and society at large, with more thoughtful and caring people.

\section{Author Biography}

Sage Streight is a 2019 graduate from the University of Waterloo, and holds a Bachelor's degree in Peace and Conflict Studies, Legal Studies and Sociology. Her undergrad experience was primarily filled with learning about issues of justice, finding a passion for conflict resolution, and being inspired by those pursuing peace at the University of Waterloo and in the KW region. This paper was written for a Peace and Conflict Studies class that focused on conflict resolution in the classroom. The course discussed many themes present in this paper, but she wanted to dive deeper into the specific practice of restorative justice circles. This class pushed her to understand the incredible impact conflict resolution processes and experiences influence individuals, relationships, and communities at a grade school level. In her research she found circles to be highly effective and simple to implement. This inspired the paper and desire to see it published so others could learn as well. 


\section{Works Cited}

Braithwaite, J. (2001). Youth Development Circles. Oxford Review of Education, 27(2), 239-252. Retrieved from http://www.jstor.org/stable/1050682

Cameron, L. \& Thorsborne, M. (1999). Restorative justice and school discipline: mutually exclusive? A practitioner's view of the impact of community conferencing in Queensland schools, paper presented at the Annual Conference of the Australia and New Zealand Education. Retrieved from http://citeseerx.ist.psu.edu/viewdoc/download?doi=10.1.1.596.5968\&rep=rep $1 \&$ type $=$ pdf

Coates, R., Umbreit, M., \& Vos, B. (2003). Restorative justice circles: An exploratory study. Contemporary Justice Review, 6(3), 265-278. doi:10.1080/1028258032000115985

Drewery, W. (2004), Conferencing in schools: punishment, restorative justice, and the productive importance of the process of conversation. J. Community. Soc. Psychol, 14, 332-344. doi:10.1002/casp.800

Friedman, Cassidy. "Restorative Justice in Oakland Schools: Tier One. Community Building Circle." YouTube, YouTube, 9 Oct. 2018 www.youtube.com/watch?v=RdKhcQrLD1w

Gregory, A., Clawson, K., Davis, A., \& Gerewitz, J. (2015). The promise of restorative practices to transform teacher-student relationships and achieve equity in school discipline. Journal of Educational and Psychological Consultation, 25, 1-29. Retrieved from http://www.antoniocasella.eu/restorative/Gregory_ RJ_2015.pdf

Gunn, Jennifer. (2018) Social Emotional Learning Activities: Classroom Circles. Concordia UniversityPortland Education. Retrieved from cu-portland.edu/blog/classroom-resources/social-emotional-learning-circles/

Karp, D., \& Breslin, B. (2001). Restorative justice in school communities. Youth \& Society, 33(2), 249-272. doi:10.1177/0044118X01033002006

Morrison, Brenda. (2005). Building Safe and Healthy School Communities: Restorative Justice and Responsive Regulation. International Institute for Restorative Practices. Retrieved from https://www.iirp.ed $\mathrm{u} /$ eforum-archive/building-safe-and-healthy-school-communities-restorative-justice-and-responsive-re gulation

Morrison, Brenda. (2003). Regulating safe school communities: being responsive and restorative. Journal of Educational Administration, Vol. 41 Issue: 6, pp.690-704, https://doi.org/10.1108/09578230310504661

Ortega, L., Lyubansky, M., Nettles, S., \& Espelage, D. L. (2016). Outcomes of a restorative circles program in a high school setting. Psychology of Violence, 6(3),n459-468. http://dx.doi.org/10.1037/vio0000048

Pakan, Nicole, \& The Society for Safe and Caring Schools and Communities (2007). Restorative Justice Community/Classroom Conferencing: A Guide for Parents and Teachers. Retrieved from http://safeandcaring.ca/wpcontent/uploads/2013/08/Restorative-Justice-booklet- Web-version.pdf

Varnham, S. (2005). Seeing things differently: Restorative justice and school discipline 1. Education and the Law, 17(3), 87-104. doi:10.1080/09539960500334061 